Journal of Environmental Science and Sustainable Development

$12-31-2018$

\title{
ACCOUNTING FOR THE ENVIRONMENTAL IMPACTS ASSOCIATED WITH RESIDUAL PRODUCTS IN A COMPARATIVE LIFE CYCLE ASSESSMENT OF SYSTEMS WITH MULTIPLE PRODUCTS
}

Yasuhiro Fukushima

Department of Chemical Engineering, Graduate School of Engineering, Tohoku University, fuku@sis.che.tohoku.ac.jp

Satoshi Ohara

Process Development Laboratories, Asahi Group Holdings

Follow this and additional works at: https://scholarhub.ui.ac.id/jessd

Part of the Sustainability Commons

\section{Recommended Citation}

Fukushima, Yasuhiro and Ohara, Satoshi (2018). ACCOUNTING FOR THE ENVIRONMENTAL IMPACTS ASSOCIATED WITH RESIDUAL PRODUCTS IN A COMPARATIVE LIFE CYCLE ASSESSMENT OF SYSTEMS WITH MULTIPLE PRODUCTS. Journal of Environmental Science and Sustainable Development, 1(1), 1-11. Available at: https://doi.org/10.7454/jessd.v1i1.17

This Original Research Article is brought to you for free and open access by the School of Environmental Science at UI Scholars Hub. It has been accepted for inclusion in Journal of Environmental Science and Sustainable Development by an authorized editor of UI Scholars Hub. 


\title{
ACCOUNTING FOR THE ENVIRONMENTAL IMPACTS ASSOCIATED WITH RESIDUAL PRODUCTS IN A COMPARATIVE LIFE CYCLE ASSESSMENT OF SYSTEMS WITH MULTIPLE PRODUCTS
}

\author{
Yasuhiro Fukushima ${ }^{1, *}$ and Satoshi Ohara ${ }^{2}$ \\ ${ }^{1}$ Department of Chemical Engineering, Graduate School of Engineering, Tohoku University, \\ Sendai, Japan \\ ${ }^{2}$ Process Development Laboratories, Asahi Group Holdings Ltd., Ibaraki, Japan \\ ${ }^{*}$ Corresponding author: e-mail: fuku@sis.che.tohoku.ac.jp
}

(Received: 20 November 2018; Accepted: 23 December 2018; Published: 28 December 2018)

\begin{abstract}
In many production systems, multiple products are interactively produced. Therefore, an innovative technology that leads to changes in parts of such systems may influence both the unit environmental impacts associated with the products, and the productivity of multiple products. To compare alternative technologies on a common basis, we often account for the avoided or supplemented emissions associated with the residual (i.e. surplus and supplemented) products produced from within the considered system boundary. In this study, using an example of an innovative technology envisioned for use in sugar mills, we first demonstrate how comparisons can be made when the systems vary in product type and quantity. Then, through sensitivity analysis, we highlight how the variations in rationales to trace the avoided emissions influence the assessment results. We identify 1) regional and temporal variance and 2) market response patterns as the items that construct the rationales to account for the avoided or supplemented emissions associated with the compared residual productions. To better assist the comparative technological life cycle assessments (LCAs), it is suggested to elaborate on the latter, by thoroughly describing the factors that may affect the ways in which the market responds to the different quantities of products from the compared systems. The study successfully provides a working example to elaborate on the discussions and arguments made by a recent study on how methodological developments in future LCA studies should be made.
\end{abstract}

Keywords: avoided greenhouse gas emissions; comparative life cycle assessment; functional unit; multiple products

\section{Introduction}

In many production systems, multiple products are interactively produced (Gheewala, Bonnet, Prueksakorn \& Nilsalab, 2011). In the case of biorefineries, there are usually multiple constituents extracted from the raw material (i.e. plants). Parts, if not all, of these are converted, purified and shipped as products (Choi et al., 2019). During this process, many biorefineries utilize residues to produce the heat and power required for the production. Therefore, it is also possible to supply heat and power, in addition to the biomass-derived 
chemicals (Kikuchi, Kanematsu, Sato \& Nakagaki, 2016; Ouchida, Hattori, Terajima, Okubo \& Kikuchi, 2018).

An innovative technology that makes changes in parts of such a production system may influence both the unit environmental impacts and the productivity of multiple products at the same time. An example is the utilization of part of the biomass for the production of the heat and power consumed in the process. This approach will reduce the input of external fuels, which is a positive factor that contributes to the reduction in greenhouse gas (GHG) emissions. However, this effect is offset by the reduced production of coproducts, because some of the raw materials are diverted to supply energy utilities. Likewise, both the quantity and balance of the inputs and the outputs are influenced as a result of the introduction of alternative technology.

In product life cycle assessment (LCA) studies, the environmental impacts that arise from a process are allocated to all the products that have some economic value. The methods and related allocation issues in the case of bioethanol production have been discussed in the literature (Kim \& Dale, 2002; Luo, Voet, Huppes, \& Haes, 2009). The greenhouse gas emissions associated with ethanol production in Brazil were calculated in a pioneering study (Macedo, Seabra, \& Silva, 2008), and many subsequent studies have applied the allocation approach to compare differences in feedstock (Muñoz et al., 2014); in regions (Khatiwada, Venkata, Silveira, \& Johnson, 2016; Nguyen \& Gheewala, 2008); and in conversion processes (Gopal \& Kammen, 2009). Many of the LCA studies present the environmental impacts allocated to products, and comparison between systems with different processes is made indirectly by observing the environmental impacts allocated to bioethanol. However, the differences that are observed can be broken down to various reasons, ranging from technology; environmental conditions (Fukushima et al., 2018), such as solar irradiation, temperature and rainfall; and economic conditions, such as the market price of the coproducts, which affects the economic allocation of the environmental impacts. A more coherent way to compare the differences in technologies used for production is needed.

Yang \& Heijungs (2018) argue that, "Instead of trying to always include everything, we argue for a flexible, and market-based system boundary tailored to the decision in question, particularly considering the scale of potential changes it may cause and how it may affect the economy." It should be understood that their recommendation is not to manipulate the boundaries to justify any specific objective. Instead, they emphasize the importance of appropriate modeling of the consequences of the changes caused by the solutions that are under investigation. In this study, we provide a concrete example of the extent to which the consequence models can influence the results of an LCA study, using our own example. We first make a comparison of multiple systems with alternative technologies by applying the comparative approach in LCA. A sugar mill is taken as a typical example, as it produces multiple products, i.e., sugar, ethanol and power. Using this example, we discuss how rational modeling of a market reaction is essential in estimating the implications of new technology. In a comparative LCA study, the incompleteness of system boundaries in process-based LCA studies is relatively unimportant, and the significance of the rational modeling of consequences in the market is more apparent. We achieve this objective by conducting sensitivity analysis of avoided GHG emissions in a comparative LCA between two types of system. 


\section{Methods}

\subsection{Case Study}

The case study in this paper assesses the potential for the reduction in GHG emissions by alternative sugarcane-based industrial systems, compared with the current sugar producing system (ref) in Japan. The following two systems are assessed: (a) the conventionally proposed system for producing ethanol from molasses without changing the sugarcane variety or sugar milling processes (Macedo et al., 2008; Ohara et al., 2018; Ouchida et al., 2017; Takriti, Searle, \& Pavlenko, 2017); and (b) the recently proposed system that enhances the production of sugar, ethanol and electricity using a high-yielding sugarcane variety and the juice pretreatment process (Kato et al., 2016; Kikuchi, Ouchida, Kanematsu, Ohara, \& Fukushima, 2017; Ohara et al., 2012; Ohara, Kato, Fukushima \& Sakoda, 2013). Figure 1 shows the productivity of coproducts in the three systems (Ohara et al., 2019).

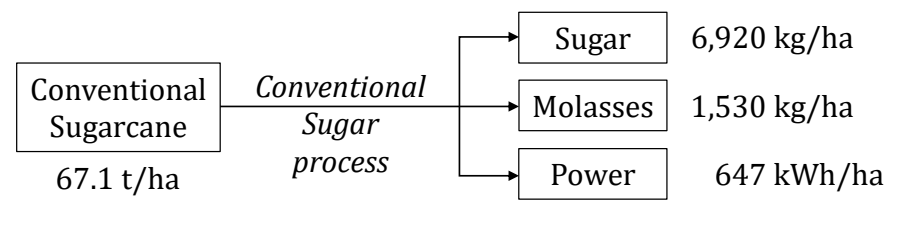

(a)
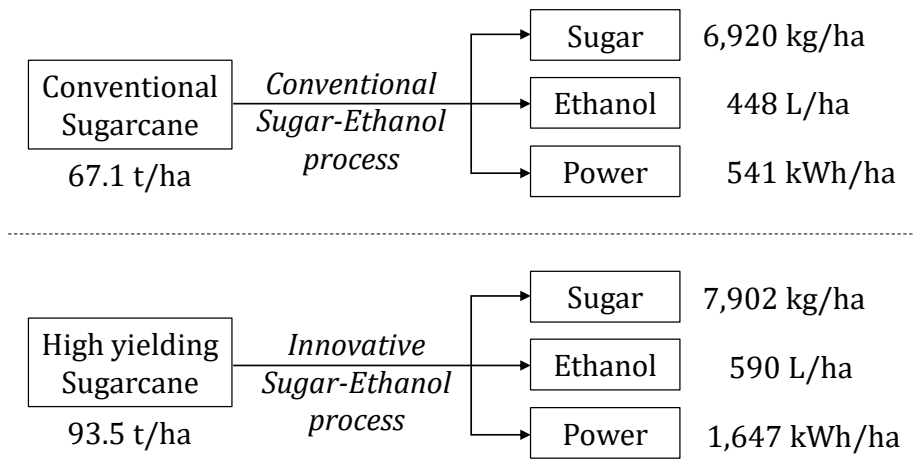

Figure 1. Productivity of systems; (ref) current sugar producing system; (a) conventional sugar-ethanol co-production system; (b) recently proposed system with raw material intensification coupled with juice pretreatment using selective fermentation

(Source: Ohara et al., 2019)

To quantify the changes in life cycle GHG emissions, a system boundary was set, as shown in Figure 2. GHG emissions include those of $\mathrm{CO}_{2}, \mathrm{CH}_{4}$ and $\mathrm{N}_{2} \mathrm{O}$, which were calculated using their global warming potential according to the IPCC $4^{\text {th }}$ assessment report $\left(\mathrm{GWP}_{100}: \mathrm{CO}_{2}=1, \mathrm{CH}_{4}=25, \mathrm{~N}_{2} \mathrm{O}=298\right)$ (The International Panel on Climate Change (IPCC), 2007), which converts the emissions into $\mathrm{CO}_{2}$ emission equivalents $\left[\mathrm{kg}-\mathrm{CO}_{2}\right.$-eq. $]$ on the basis of absorption capability of infrared radiation with the time horizon of 100 years considering the lifetime of each species in the atmosphere. Assuming that the considered technology options will not lead to the changes in the area of farmland, the production activity attributable to 1 ha $\left(=10,000 \mathrm{~m}^{2}\right)$ of the farmland $\left(\mathrm{t}-\mathrm{CO}_{2}\right.$-eq./ (ha.year)) was compared (Table 1). By introducing the a) conventional and b) recently proposed systems, GHG

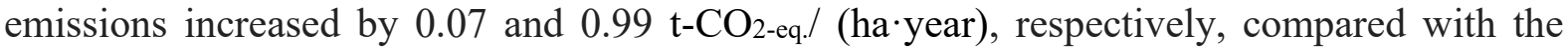
current situation (5.94 t- $\mathrm{CO}_{2 \text {-eq. }}$ ( (ha-year)). Table 2 shows the $\mathrm{GHG}$ emissions attributed to a unit quantity of product in each system. Economic value-based partitioning of emissions was 
applied (sugar: 83.1 JPY/kg, ethanol: 53.7 JPY/L, power: 16.5 JPY/kWh, JPY stands for Japanese Yen) to allocate the calculated GHG emissions (Ohara et al., 2019).

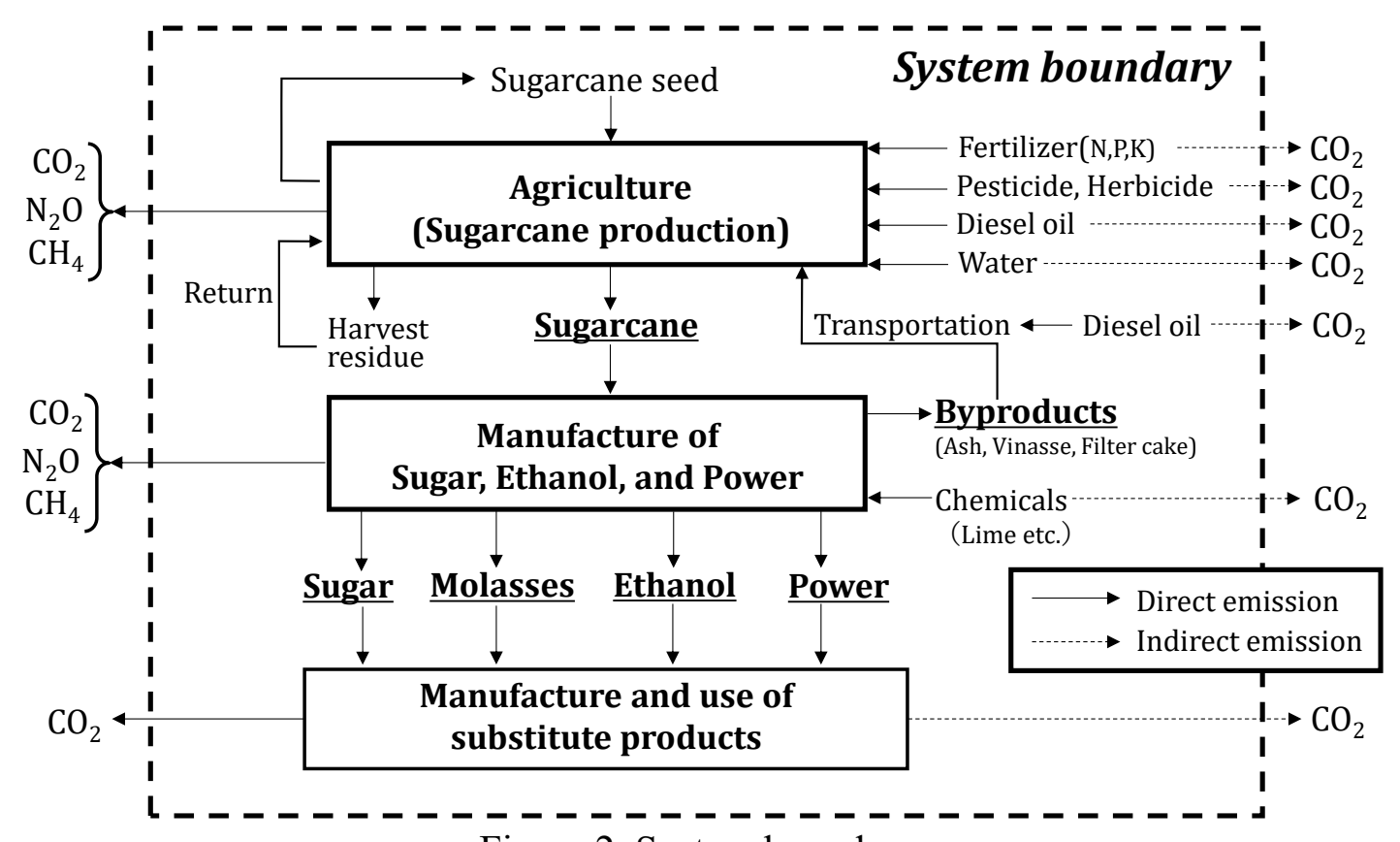

Figure 2. System boundary

Table 1. GHG emissions from the compared systems*

\begin{tabular}{|l|c|}
\hline \multicolumn{1}{|c|}{ System } & GHG emission $\left(\boldsymbol{t}-\boldsymbol{C O}_{2 \text {-eq }} / \boldsymbol{h a}\right)$ \\
\hline Reference system & 5.94 \\
\hline Conventional system & 6.01 \\
\hline Recently proposed system & 6.93 \\
\hline
\end{tabular}

*This comparison alone does not conclude the preference based on GHG emission, because the products from these systems are varied as summarized in Figure 1

Table 2. GHG emissions allocated to the co-products in the investigated alternative systems ${ }^{* *}$

\begin{tabular}{|c|c|c|c|c|}
\hline \multirow[b]{2}{*}{ Product } & \multicolumn{4}{|c|}{ GHG emissions } \\
\hline & Unit & $\begin{array}{c}\text { (ref) Current } \\
\text { system }\end{array}$ & $\begin{array}{c}\text { (a) Conventional } \\
\text { system }\end{array}$ & $\begin{array}{c}\text { (b) Recently } \\
\text { proposed system }\end{array}$ \\
\hline Sugar & $\left(\mathrm{kg}-\mathrm{CO}_{2 \text {-eq. }} / \mathrm{kg}\right)$ & 0.836 & 0.822 & 0.805 \\
\hline Ethanol & $\left(\mathrm{kg}-\mathrm{CO}_{2 \text {-eq. }} / \mathrm{L}\right)$ & - & 0.531 & 0.520 \\
\hline Power & $\left(\mathrm{kg}-\mathrm{CO}_{2 \text {-eq }} / \mathrm{kWh}\right)$ & 0.166 & 0.163 & 0.160 \\
\hline Molasses & $\left(\mathrm{kg}-\mathrm{CO}_{2 \text {-eq. }} / \mathrm{kg}\right)$ & 0.030 & - & - \\
\hline
\end{tabular}

${ }^{* *}$ It is difficult to discuss how each system contributes to the changes in overall GHG emissions, because the produced quantity of coproducts is varied in the respective systems (Figure 2)

\subsection{Sensitivity Analysis of the Residual Products in Comparative LCA}

To compare the implications for the environmental impacts (for example GHG emissions) caused by alternative technologies, a common basis of production for all the products must be set. The residual (surplus or supplemented) products produced from the system boundary 
(Figure 3) in the investigated systems are then accounted for as avoided or supplemented emissions. Avoided emissions derive from the substituted products, which have the same function as the surplus products from the set standard. Supplemented emissions, on the other hand, are calculated by accounting for the additional consumption of products to reach the standard production. This approach has already been taken by studies comparing varied practices in agriculture. A common base is set on the area of farmland, and differences in products are assessed comparatively, such as in the studies of Ohara et al. (2009) and Nakashima and Ishikawa (2016).

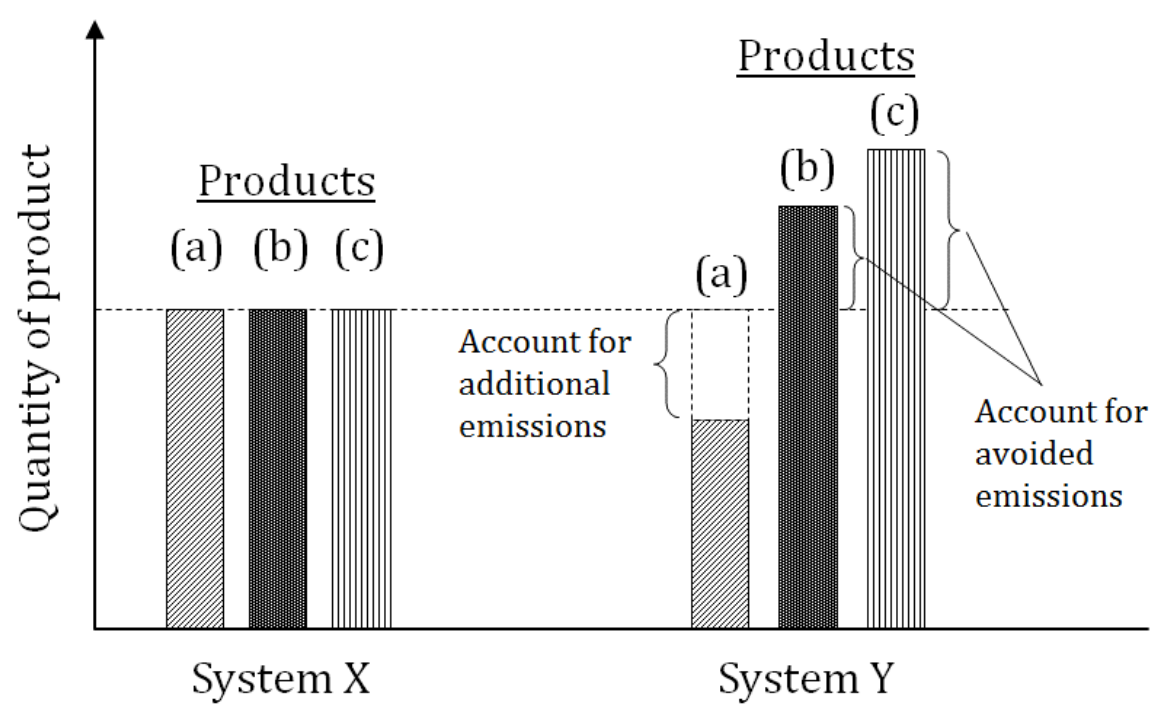

Figure 3. Comparison of systems with varied production

Table 3 summarizes the potentially substituted products and their inventories of life cycle GHG emissions. Regarding sugar production, which is increased by the introduction of systems (a) and (b), cases substituting (S1), the domestic sugar derived from sugarcane and beet in Japan, and (S2), imported sugar from Thailand, the largest exporter to Japan, were examined. As a substitute for ethanol, cases substituting (E1), imported gasoline, and (E2), imported ethanol from Brazil, the only exporter to Japan, were examined. The gasoline equivalent of the combustion energy of $1 \mathrm{~L}$ of ethanol was set at $0.644 \mathrm{~L}$, on the basis of its lower heating values (LHV). For electric power, cases substituting (P1), the grid electricity in the area where the sugar mill is located in Japan, and (P2), the grid electricity derived from the thermal power generation in the same area, were examined. Since the production of molasses as a byproduct disappears due to ethanol production, it is necessary for the other industries that use molasses as a secondary ingredient to purchase these from other sugar mills. Therefore, the GHG emissions generated by new molasses procurement were considered using a GHG emission life cycle inventory of molasses in the present system (Table 2). 
Table 3. Inventories of life cycle GHG emission per a functional unit of the substituted products, "production" includes transportation that comes in between the production activities

\begin{tabular}{|c|c|c|c|c|}
\hline \multirow{2}{*}{ Product } & \multirow{2}{*}{$\begin{array}{l}\text { Substituted } \\
\text { product }\end{array}$} & \multicolumn{2}{|l|}{ GHG emission } & \multirow{2}{*}{$\begin{array}{c}\text { Data } \\
\text { source }\end{array}$} \\
\hline & & Unit & Amount & \\
\hline \multirow{2}{*}{ Sugar } & $\begin{array}{l}\text { (S1) Domestic Sugar } \\
\text { (Sugarcane \& Beet) }\end{array}$ & $\begin{array}{l}\text { Production } \\
\left(\mathrm{kg}-\mathrm{CO}_{2 \text {-eq. }} / \mathrm{kg}\right)\end{array}$ & 0.951 & (1) \\
\hline & $\begin{array}{l}\text { (S2) Imported Sugar } \\
\text { (From Thailand) }\end{array}$ & $\begin{array}{l}\text { Production } \\
\left(\mathrm{kg}-\mathrm{CO}_{2 \text {-eq }} / \mathrm{kg}\right)\end{array}$ & 0.203 & (2) \\
\hline \multirow{2}{*}{ Ethanol } & $\begin{array}{l}\text { (E1) Imported Gasoline } \\
\text { (Japan Average) }\end{array}$ & $\begin{array}{l}\text { Production }\left(\mathrm{kg}-\mathrm{CO}_{2 \text {-eq. }} / \mathrm{L}\right) \\
\text { Use }\left(\mathrm{kg}-\mathrm{CO}_{2 \text {-eq }} / \mathrm{L}\right)\end{array}$ & $\begin{array}{l}0.365 \\
2.724\end{array}$ & (3) \\
\hline & $\begin{array}{l}\text { (E2) Imported Ethanol } \\
\text { (From Brazil) }\end{array}$ & $\begin{array}{l}\text { Production } \\
\left(\mathrm{kg}-\mathrm{CO}_{2 \text {-eq }} / \mathrm{L}\right)\end{array}$ & 0.693 & (4) \\
\hline \multirow[t]{2}{*}{ Power } & $\begin{array}{l}\text { (P1) Local Power } \\
\text { (Thermal Power } \\
\text { in Kyushu) }\end{array}$ & $\begin{array}{l}\text { Production } \\
\left(\mathrm{kg}-\mathrm{CO}_{2 \text {-eq. }} / \mathrm{kWh}\right)\end{array}$ & 0.764 & $(5),(6)$ \\
\hline & $\begin{array}{l}\text { (P2) Local Power } \\
\text { (Tanegashima) }\end{array}$ & $\begin{array}{l}\text { Production } \\
\left(\mathrm{kg}-\mathrm{CO}_{2 \text {-eq }} / \mathrm{kWh}\right)\end{array}$ & 0.528 & (5) \\
\hline
\end{tabular}

(Source (1): Japan Environmental Management Association for Industry (JEMAI), 2012; (2): Hattori, Suzuki, Ebashi, Ota, \& Sato, 2008, (3): Ecoinvent, 2010; (4): Mitsubishi Research Institute Inc., 2017, (5): Kyushu Electric Power Co. Inc., 2018; (6): Imamura, Iuchi, \& Bando, 2016)

\section{Results and Discussions}

\subsection{Sensitivity Analysis of Avoided GHG Intensity in Life Cycle GHG emissions}

From our results (Figure 4), we have successfully highlighted the importance of the appropriate modeling of market consequences. These results stand as a concrete example of the statement made by Yang \& Heijungs (2018). Figure 4 shows the results of the GHG life cycle of (a) the conventional system and (b) the innovative system, with regard to changing the combination of substituted products from Case 1 to Case 8, with the emissions in the current system (ref.) as the base case.

From the viewpoint of the GHG emission reduction potential in comparison to (ref), i.e., the difference between the GHG life cycle, (ref) and the investigated systems (a and b), Cases 3 and 7 in (a), and Case 1 in (b) show the highest reduction effect, determined by how the substituted products were assumed. When Brazilian ethanol with a low emission intensity was selected as the substituted product for the ethanol additionally produced in (b) and (c), this production does not contribute as much as in the cases, in which it substitutes for gasoline consumption. In many studies, including that of Nakashima \& Ishikawa (2016), which presents a similar framework for comparison in the case of sugarcane derived bioethanol, the produced bioethanol is assumed to replace gasoline consumption. However, if the composition of ethanol mixed with gasoline is regulated by policy, an alternative situation in which a replacement takes place with bioethanol may occur. It is thus important to ensure the level of demand for bioethanol which currently exists, and in the future in the region from where the ethanol can be transported in an economically feasible manner, and how policy institutionalizes the introduction of bioethanol as a fuel. Likewise, in case 6 , the assumption 
on avoided electric power is proven to be crucial. When power derived from thermal generation with high emission intensity is substituted, it can contribute positively. However, if it merely contributes to oversupply in the power grid, an energy storage solution must also be provided. Scenario verification as such is especially crucial for countries such as Japan and Indonesia, where grid systems are loosely, but not intensively, connected as a network due to their geographic configuration.

In light of the comparison between (b) and (c), the difference in the reduction of the GHG life cycle changes from large to small in the order of Case 1 to Case 8. In (c), the production of sugar, ethanol and electricity all increase. Therefore, the difference in GHG emission reduction achieved is more significant than that in (b), in which substituted products with high emission intensity were selected. In contrast, in Case 8, (b) was more effective in reducing emissions than (c). When choosing substitute products with a low emission intensity, such as imported sugar from Thailand, imported ethanol from Brazil and regional power, the increase in emissions resulting from increased production and the avoidance of emissions from the substituted products are almost equal, offsetting the contribution to emission reductions.

\begin{tabular}{|c|c|c|c|c|c|c|c|c|c|c|c|c|c|c|c|c|c|c|}
\hline \multirow{2}{*}{\multicolumn{2}{|c|}{$\begin{array}{l}\text { Case } \\
\text { System }\end{array}$}} & \multirow{3}{*}{$\begin{array}{c}\text { Base } \\
\text { Cur. } \\
-\end{array}$} & \multicolumn{2}{|c|}{ Case1 } & \multicolumn{2}{|c|}{ Case2 } & \multicolumn{2}{|c|}{ Case3 } & \multicolumn{2}{|c|}{ Case4 } & \multicolumn{2}{|c|}{ Case5 } & \multicolumn{2}{|c|}{ Case6 } & \multicolumn{2}{|c|}{ Case7 } & \multicolumn{2}{|c|}{ Case8 } \\
\hline & & & Conv. & Inv. & Conv. & Inv. & Conv. & Inv. & Conv. & Inv. & Conv. & Inv. & Conv. & Inv. & Conv. & Inv. & Conv. & Inv. \\
\hline \multirow{3}{*}{$\begin{array}{l}\text { Substituted } \\
\text { products }\end{array}$} & Sugar & & \multicolumn{2}{|c|}{ S1 } & \multicolumn{2}{|c|}{ S1 } & \multicolumn{2}{|c|}{ S1 } & \multicolumn{2}{|c|}{ S1 } & \multicolumn{2}{|c|}{ S2 } & \multicolumn{2}{|c|}{ S2 } & \multicolumn{2}{|c|}{ S2 } & \multicolumn{2}{|c|}{ S2 } \\
\hline & Power & - & \multicolumn{2}{|c|}{ P1 } & \multicolumn{2}{|c|}{ P1 } & \multicolumn{2}{|c|}{ P2 } & \multicolumn{2}{|c|}{ P2 } & \multicolumn{2}{|c|}{ P1 } & \multicolumn{2}{|c|}{ P1 } & \multicolumn{2}{|c|}{ P2 } & \multicolumn{2}{|c|}{ P2 } \\
\hline & Ethanol & - & \multicolumn{2}{|c|}{ E1 } & \multicolumn{2}{|c|}{ E2 } & \multicolumn{2}{|c|}{ E1 } & \multicolumn{2}{|c|}{ E2 } & & & \multicolumn{2}{|c|}{ E2 } & \multicolumn{2}{|c|}{ E1 } & \multicolumn{2}{|c|}{ E2 } \\
\hline
\end{tabular}

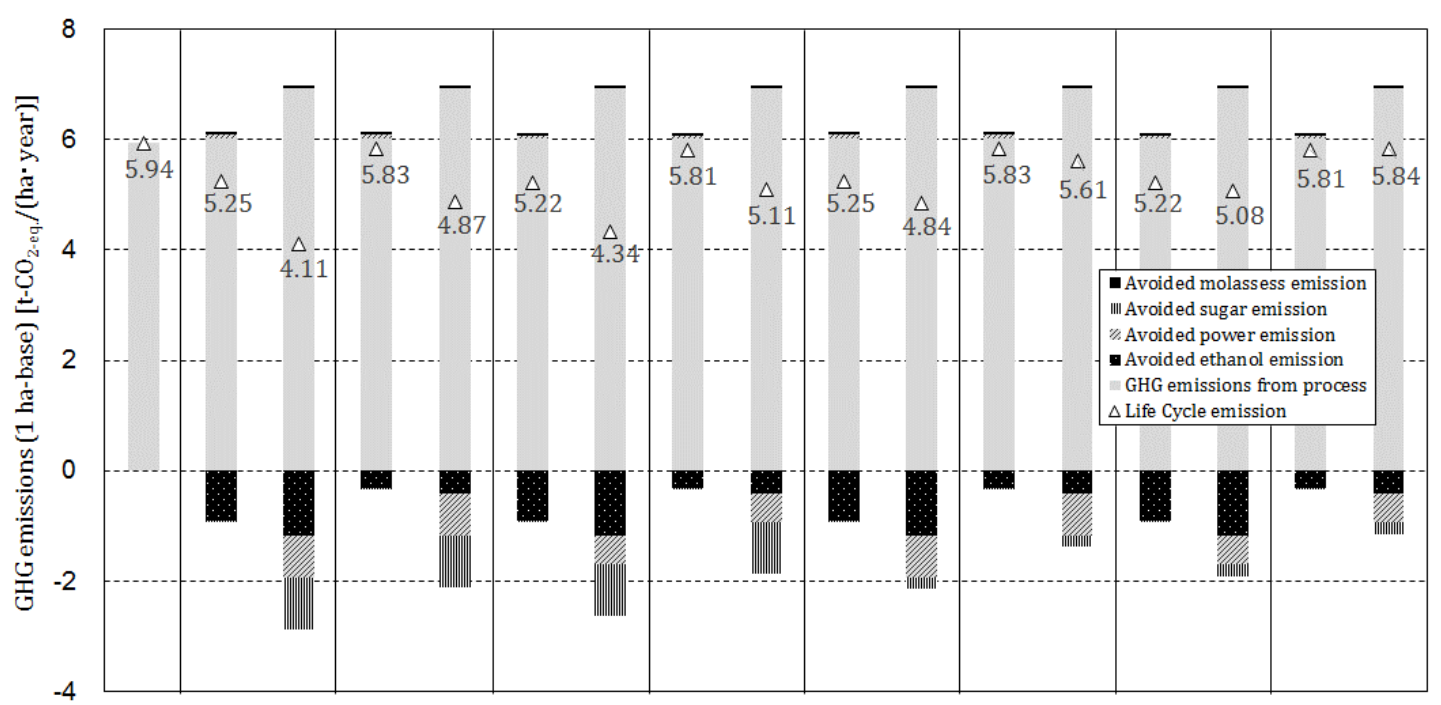

Figure 4. Life cycle GHG emission in each case (1 ha of farmland base)

\subsection{The Findings in Relation to Future Studies}

The results presented in Figure 4 show how important it was to rationally model the avoided emissions caused by the residual products in the compared systems in relation to the decisions in question. It is therefore critical to check the sensitivity of the results against the variances in the emission inventories used in the accounting of the avoided and induced emissions in the background systems.

It is also essential to correctly set the system boundary for the analysis; in this study, the boundary was set so that most of the systems responsible for indirect emissions were 
common among the compared systems. In this way, system incompleteness concerning the breadth of the life cycle systems is unimportant, as it does not contribute in the comparison results. It must be noted that in this way the system boundary definition reflects part of the assumptions on the market response mechanisms. A definition of the system boundary is therefore necessary in a comparative LCA.

In this study, we have identified and presented two major factors in the modeling of the avoided emissions in a comparative LCA. The first of these is regional and temporal variances. How products are supplied to consumers in a region often differs significantly; this is especially the case for energy. However, some products are also the case. It is important to investigate how additional products would contribute in the reduction of, or addition to, emissions in relation to a particular region. Specifically, for technology assessment that may be accompanied by investment in equipment over a long period, or for those that could be used as a product for a long period, it is also essential to consider temporal variances. Future changes in how and to what extent the avoided and supplemented emissions occur must be consistently assumed in scenarios that are investigated. For example, Japan is envisioning a significant lowering of carbon emissions in electric energy consumption by 2030; the target set by the power suppliers is $0.37 \mathrm{~kg}-\mathrm{CO}_{2} / \mathrm{kWh}$ (Federation of Electric Power Companies of Japan (FEPC), 2015). Use of such numbers must be considered to assess the reduction potentials in the future, which can result in a conservative estimation of reduction effects compared to the case where a current emission inventory $\left(0.512 \mathrm{~kg}-\mathrm{CO}_{2}\right.$-eq. $\left./ \mathrm{kWh}\right)$ is used (Ministry of the Environment of Government of Japan, 2017). The second factor is the economic reaction of the market. This is highlighted by the way additional ethanol would be accounted for. It should be noted that in reality the two factors above should be taken into account concurrently. For example, if government policy is to reduce national emissions to meet their committed target, they must ensure that under the market mechanisms determined by the policies, any additional ethanol production would lead to a reduction in emissions within the nation.

There may be other factors that influence how avoided emissions should be modeled, and how the system boundary should be set in a comparative LCA. A complete framework for modeling the market reactions to the changes caused by an envisioned scenario is required, which related to the various types of decision contexts.

\section{Conclusions}

In this paper, we have demonstrated that the dominant uncertainty in the results of a comparative LCA study would be sourced in both the modeling of direct emissions within the system boundary and in the assumptions of how the avoided or supplemented emissions associated with the varied production patterns in the compared systems contribute to environmental impacts; for example, GHG emissions. In the study, we have proposed 1) regional and temporal variance and 2) market response patterns as the types of rationale to account for the avoided or added emissions associated with the compared residual productions. To better assist comparative LCAs in technological assessment, it is suggested that LCA researchers and practitioners determine further factors that may affect the ways the market can respond to the varied quantity of products from the envisioned and evaluated systems. 


\section{References}

Choi, J. H., Jang, S. K., Kim, J. H., Park, S. Y., Kim, J. C., Jeong, H., ... Choi, I. G. (2019). Simultaneous production of glucose, furfural, and ethanol organosolv lignin for total utilization of high recalcitrant biomass by organosolv pretreatment. Renewable Energy, 130, 952-960. https://doi.org/10.1016/j.renene.2018.05.052

Ecoinvent. (2010). ecoinvent v2.2. Retrieved from https://www.ecoinvent.org/home.html

Federation of Electric Power Companies of Japan (FEPC). (2015). $\mathrm{CO}_{2}$ emissions from the electric power business. Retrieved November 14, 2018, from http://www.fepc.or.jp/about_us/pr/pdf/kaiken_s_20170616.pdf

Fukushima, Y., Nakamura, R., Ohno, H., Ohara, S., Kikuchi, Y., Ouchida, K., ... Sugimoto, A. (2018). Statistics-based yield estimation model for designing integrated plant resource utilization system considering interannual meteorological variances: implications from case studies on combined sugar-ethanol production from sugarcane. Journal of Life Cycle Assessment, Japan, 14(4), 302-318. https://doi.org/10.3370/lca.14.302

Gheewala, S. H., Bonnet, S., Prueksakorn, K., \& Nilsalab, P. (2011). Sustainability Assessment of a Biorefinery Complex in Thailand. Sustainability, 3(3), 518-530. https://doi.org/10.3390/su3030518

Gopal, A. R., \& Kammen, D. M. (2009). Molasses for ethanol: The economic and environmental impacts of a new pathway for the lifecycle greenhouse gas analysis of sugarcane ethanol. Environmental Research Letters, 4(4), 1-5. https://doi.org/10.1088/1748-9326/4/4/044005

Hattori, K., Suzuki, A., Ebashi, T., Ota, M., \& Sato, K. (2008). The calculation of carbon dioxide emission intensity from sugarcane to refined sugar. Proceedings of the Research Society of Japan Sugar Refineries' Technologists, 56, 29-35.

Imamura, E., Iuchi, M., \& Bando, S. (2016). Comprehensive assessment of life cycle CO2 emissions from power generation technologies in Japan. Retrieved November 14, 2018, from https://criepi.denken.or.jp/jp/kenkikaku/report/detail/Y06.html

Japan Environmental Management Association for Industry (JEMAI). (2012). CFP database ver. 4.0. Carbon Footprint Program. Retrieved November 14, 2018, from https://www.cfp-japan.jp/calculate/verify/pdf/CO2kansanryo_db_ver4_jp_20120330.pdf/

Kato, T., Ohara, S., Fukushima, Y., Sugimoto, A., Masuda, T., Yasuhara, T., \& Yamagishi, H. (2016). Development of flocculent Saccharomyces cerevisiae strain GYK-10 for the selective fermentation of glucose/fructose in sugar mills. Journal of Bioscience and Bioengineering, 122(1), 58-63.

Khatiwada, D., Venkata, B. K., Silveira, S., \& Johnson, F. X. (2016). Energy and GHG balances of ethanol production from cane molasses in Indonesia. Applied Energy, 164, 756-768. https://doi.org/10.1016/j.apenergy.2015.11.032

Kikuchi, Y., Kanematsu, Y., Sato, R., \& Nakagaki, T. (2016). Distributed Cogeneration of Power and Heat within an Energy Management Strategy for Mitigating Fossil Fuel Consumption. Journal of Industrial Ecology, 20(2), 289-303. https://doi.org/10.1111/jiec.12374

Kikuchi, Y., Ouchida, K., Kanematsu, Y., Ohara, S., \& Fukushima, Y. (2017). Retrofit energy integration for selective fermentation in cane sugar mills under hot/cold energy 
availability. Journal of Chemical Engineering of Japan, 50(4), 297-308. https://doi.org/10.1252/jcej.16we130

Kim, S., \& Dale, B. E. (2002). Allocation Procedure in Ethanol Production System from Corn Grain-I. System expansion. International Journal of Life Cycle Assessment, 4, 237-243. https://doi.org/10.1007/BF02978879

Kyushu Electric Power Co. Inc. (2018). Data book 2018. Fukuoka. Retrieved from http://www.kyuden.co.jp/company_data_book.html

Luo, L., Voet, E. Van Der, Huppes, G., \& Haes, H. A. Udo De (2009). Allocation issues in LCA methodology: A case study of corn stover-based fuel ethanol. International Journal of Life Cycle Assessment, 14(6), 529-539. https://doi.org/10.1007/s11367-009-0112-6

Macedo, I. C., Seabra, J. E. A., \& Silva, J. E. A. R. (2008). Green house gases emissions in the production and use of ethanol from sugarcane in Brazil: The 2005/2006 averages and a prediction for 2020. Biomass and Bioenergy, 32(7), 582-595. https://doi.org/10.1016/j.biombioe.2007.12.006

Ministry of the Environment of Government of Japan. (2017). Emission factor by electric power supplier. Retrieved November 14, 2018, from https://ghgsanteikohyo.env.go.jp/files/calc/h30_coefficient_rev.pdf

Mitsubishi Research Institute Inc. (2017). Survey on the way of fuel policy in Japan centering on biofuels. Retrieved November 14, 2018, from http://www.meti.go.jp/meti_lib/report/H28FY/000069.pdf

Muñoz, I., Flury, K., Jungbluth, N., Rigarlsford, G., I Canals, L. M., \& King, H. (2014). Life cycle assessment of bio-based ethanol produced from different agricultural feedstocks. International Journal of Life Cycle Assessment, 19(1), 109-119. https://doi.org/10.1007/s11367-013-0613-1

Nakashima, T., \& Ishikawa, S. (2016). Energy inputs and greenhouse gas emissions associated with small-scale farmer sugarcane cropping systems and subsequent bioethanol production in Japan. NJAS - Wageningen Journal of Life Sciences, 76, 43-53. https://doi.org/10.1016/j.njas.2015.11.003

Nguyen, T. L. T., \& Gheewala, S. H. (2008). Life cycle assessment of fuel ethanol from cane molasses in Thailand. International Journal of Life Cycle Assessment, 13(4), 301-311. https://doi.org/10.1007/s11367-008-0011-2

Ohara, S., Fukushima, Y., Sugimoto, A., Terajima, Y., Ishida, T., \& Sakoda, A. (2009). Reduction in Greenhouse Gas Emissions from Process Retrofitting and Cultivar Improvement in Combined Sugar-Ethanol Production from Sugarcane. Journal of Life Cycle Assessment, Japan, 5(4), 439-445. https://doi.org/10.3370/lca.5.439

Ohara, S., Fukushima, Y., Sugimoto, A., Terajima, Y., Ishida, T., \& Sakoda, A. (2012). Rethinking the cane sugar mill by using selective fermentation of reducing sugars by Saccharomyces dairenensis, prior to sugar crystallization. Biomass and Bioenergy, 42, 78-85. https://doi.org/10.1016/j.biombioe.2012.03.024

Ohara, S., Kato, T., Fukushima, Y., \& Sakoda, A. (2013). Selective ethanol production from reducing sugars in a saccharide mixture. Journal of Bioscience and Bioengineering, 115(5), 540-543. https://doi.org/10.1016/j.jbiosc.2012.11.010

Ohara, S., Kikuchi, Y., Ouchida, K., Sugimoto, A., Hattori, T., Yasuhara, T., \& Fukushima, Y. (2019). Reduction of Greenhouse Gas Emissions in the Introduction of Inversion 
System to produce Sugar and Ethanol from Sugarcane. Journal of Life Cycle Assessment, Japan, in press.

Ohara, S., Terajima, Y., Kikuchi, Y., Fukushima, Y., Yasuhara, T., \& Sugimoto, A. (2018). Pilot Scale Demonstration of Technologies for Enhancing Production of Sugar and Ethanol from Sugarcane. Kagaku Kogaku Ronbunshu, 44(4), 260-270. https://doi.org/10.1252/kakoronbunshu.44.260

Ouchida, K., Fukushima, Y., Ohara, S., Sugimoto, A., Hirao, M., \& Kikuchi, Y. (2017). Integrated Design of Agricultural and Industrial Processes: A Case Study of Combined Sugar and Ethanol Production. AIChE Journal, 63(2), 560-581. https://doi.org/10.1002/aic.15374

Ouchida, K., Hattori, T., Terajima, Y., Okubo, T., \& Kikuchi, Y. (2018). Implementation Analysis of Bagasse Power Plants Considering Technology Options on Sugarcane Cultivars and Power Plants. Kagaku Kogaku Ronbunshu, 44(2), 113-122. https://doi.org/10.1252/kakoronbunshu.44.113

Takriti, S. E., Searle, S., \& Pavlenko, N. (2017). Indirect greenhouse gas emissions of molasses ethanol in the European Union. International Council on Clean Transportation, $12,1-13$.

The International Panel on Climate Change (IPCC). (2007). Climate Change 2007-The Physical Science Basis: Working Group I Contribution to the Fourth Assessment Report (AR4) of the IPCC. Cambridge, United Kingdom and New York, USA: Cambridge Univeresity Press.

Yang, Y., \& Heijungs, R. (2018). Moving from completing system boundaries to more realistic modeling of the economy in life cycle assessment. International Journal of Life Cycle Assessment, Online. https://doi.org/10.1007/s11367-018-1532-y 